\title{
Cost-related medication nonadherence in Canada: a systematic review of prevalence, predictors, and clinical impact
}

Anne M. Holbrook ${ }^{*}$ DD, Mei Wang ${ }^{2}$, Munil Lee ${ }^{3}$, Zhiyuan Chen², Michael Garcia ${ }^{4}$, Laura Nguyen ${ }^{5}$, Angela Ford ${ }^{6}$, Selina Manji and Michael R. Law ${ }^{8}$

\begin{abstract}
Background: Cost-related nonadherence to medications (CRNA) is common in many countries and thought to be associated with adverse outcomes. The characteristics of CRNA in Canada, with its patchwork coverage of increasingly expensive medications, are unclear.

Objectives: Our objective in this systematic review was to summarize the literature evaluating CRNA in Canada in three domains: prevalence, predictors, and effect on clinical outcomes.

Methods: We searched MEDLINE, Embase, Google Scholar, and the Cochrane Library from 1992 to December 2019 using search terms covering medication adherence, costs, and Canada. Eligible studies, without restriction on design, had to have original data on at least one of the three domains specifically for Canadian participants. Articles were identified and reviewed in duplicate. Risk of bias was assessed using design-specific tools.

Results: Twenty-six studies of varying quality ( $n=483,065$ Canadians) were eligible for inclusion. Sixteen studies reported on the overall prevalence of CRNA, with population-based estimates ranging from 5.1 to $10.2 \%$. Factors predicting CRNA included high out-of-pocket spending, low income or financial flexibility, lack of drug insurance, younger age, and poorer health. A single randomized trial of free essential medications with free delivery in Ontario improved adherence but did not find any change in clinical outcomes at 1 year.
\end{abstract}

Conclusion: CRNA affects many Canadians. The estimated percentage depends on the sampling frame, the main predictors tend to be financial, and its association with clinical outcomes in Canada remains unproven.

Keywords: Medication adherence, Medication costs, Canada, Systematic review

\section{Background}

Medication cost-related nonadherence (CRNA) is defined as taking less medication than prescribed because of cost, such as delaying or failing to fill prescriptions, or skipping or lowering medication doses [1-3]. International estimates of the incidence and prevalence vary but are thought to be particularly high in the USA where

\footnotetext{
* Correspondence: holbrook@mcmaster.ca

'Division of Clinical Pharmacology \& Toxicology, Department of Medicine, McMaster University, Hamilton, ON, Canada

Full list of author information is available at the end of the article
}

many citizens are uninsured or under-insured [4-7]. Several factors have been found to be associated with nonadherence, including poor health, low household income, and disease burden [1, 8]. Cost-related factors proposed include lack of prescription drug coverage, high monthly medication cost, and high out-of-pocket costs $[1,8-12]$. As for patient outcomes associated with CRNA, increased cost sharing was associated with the increased use of health services such as hospitalization and emergency department (ED) visits among patients with a number of chronic conditions $[9,13-15]$. 
Treatment choices that patients at risk of CRNA face may lead to priorities that do not optimize health, such as choosing medications providing symptom relief only rather than important clinical benefit [16]. Other studies have suggested that higher medication adherence is associated with better outcomes and lower healthcare costs across many disease states and populations, including children [17-19]. However, all of these studies are susceptible to confounding due to their lower-quality design and the "healthy user effect"-the likelihood that adherent individuals have other unmeasured healthy behaviors [17]. Indeed, randomized trial evidence that removing financial barriers to essential medication access improves clinical outcomes is lacking. The landmark MI-FREEE trial showed that randomization to full coverage of key cardiac medications for patients postmyocardial infarction improved adherence but made no difference in the primary outcome of vascular events [20].

Although CRNA is well described in the USA and documented in other countries such as the UK and other European countries, it has not been as well characterized in Canada [21-23]. Total health expenditure in Canada was estimated to be $\$ 242$ billion in 2017, with drugs accounting for $16.4 \%$ of the total and increasing at a faster rate than other sectors [24]. Furthermore, Canadians face some of the highest medication charges in the world, and while many individuals have private coverage, provincial-territorial public plans include some with very high co-pays and deductibles $[25,26]$. Considering the effect that CRNA may have on patient outcomes and health care spending, knowledge of its prevalence, predictors, and clinical effects could help clinicians and policymakers to improve the effectiveness and costeffectiveness of patient care. National PharmaCare themes under active discussion include national formulary creation, size, and reimbursement options [27, 28].

Given the current debate on medication costs, adherence, and PharmaCare policy nationally, we aimed to systematically review the literature to determine the prevalence, predictors, and clinical outcomes of CRNA in Canada. Our research question was "Amongst Canadians of any age, what is the prevalence of CRNA, what are its predictors using multivariable analysis, and what are the resultant clinical outcomes of CRNA?"

\section{Methods}

This systematic review was designed in accordance with the most recent PRISMA statement (Additional file 1), but a review protocol was not registered [29, 30]. Eligible studies had to provide original data on at least one of the three stated objectives involving CRNA and Canadians. The following databases were searched since inception to the week of December 9, 2019: MEDLINE,
Embase, Cochrane Library, and Google Scholar. The initial search terms used for MEDLINE and Embase were as follows: prescription fees, drug adj costs, exp patient compliance, medication adherence, cost sharing, health expenditures, and Canada/ or Canada. The Cochrane library search began with the terms "cost related adherence" and "Canada" and then limited, if needed, to include only studies involving Canada. For Google Scholar, the following searches were performed: "Costrelated nonadherence" and "Canada" combined with "medications" or "drugs" or "prescriptions." No language restriction was applied. The authors of the key studies were surveyed for information on studies missed by our search or published since. The search strategy for MEDL INE is provided in Additional file 2.

Two authors screened the retrieved titles and abstracts. Articles were only included if they directly measured CRNA (i.e., not just adherence) prevalence. Studies examining the predictors of CRNA had to have used a multi-variable analysis that adjusted for multiple factors or measured differences in adherence in a randomized trial of an intervention directly targeting CRNA, or measured change in adherence immediately before and after a policy change where a change in patient costs or out-of-pocket expenses for medications is reasonably implicated. Studies examining the impact of CRNA were required to examine clinical outcomes such as hospitalization, adverse events, or disease. For example, self-reported increased health care utilization did not count. We included studies of any design without restriction on medication, age, sex, outcome, or measure of adherence. Studies were excluded if they did not report original data, were conference abstracts, or did not involve an identifiable Canadian population whose results were specified.

Articles passing through title and abstract screening underwent full-text screening then subsequent data extraction using pre-piloted forms. We extracted data on study design, sample size, CRNA definition, predictors, clinical outcomes, risk of bias, and statistical analysis. Two reviewers carried out duplicate full-text screening and data extraction independently, with differences resolved by consensus.

Risk of bias assessment was conducted using study design-specific tools. Surveys were rated on the representativeness of the sample, adequacy of response rate, missing data, pilot testing, and validity of the survey instrument, using a tool from Evidence Partners [31]. Qualitative studies were assessed using the Critical Appraisal Skills Program (CASP) checklist which asks about the appropriateness of qualitative design, recruitment, researcher-participant relationship, and data collection and analysis [32]. For pre-post studies, we assessed the intervention effect on the rate of outcomes over time, 
confounding, missing data, and selective reporting, using the Cochrane risk of bias criteria for interrupted timeseries studies [33]. An overall risk of bias rating was calculated for each study based on the percentage of low risk of bias items $(70-100 \%=$ low risk of bias, $31-69 \%=$ moderate risk, $0-30 \%=$ high risk). A summary risk of bias chart was created based on the Cochrane tool, showing each study as low, moderate, or high risk of bias [34].

Analyses planned included descriptive details of each study addressing at least one of our three components of CRNA, with additional focus on population-based studies (as opposed to disease- or drug-specific results). Quantitative data pooling of prevalence results was planned where permissible by the availability of compatible data, otherwise qualitative summaries of prevalence, predictors, and outcomes.

\section{Results}

\section{Study characteristics}

Of the 1390 articles identified by the literature searches and additional checks, 1321 were excluded based on their titles and abstracts (Fig. 1). Sixty-nine studies were screened in full text with 43 eliminated at this stage, leaving 26 included studies (study details in Table 1) [2, $3,35-58]$. Since several of these studies used the same source survey [3, 38, 39, 43, 45-48], the total sample size of unique participants across all 26 studies is uncertain. Assuming that each study's participant is a unique individual, the total sample size is 497,534 . All but one of the studies were observational, varying from surveys to large healthcare database time series, to qualitative designs. The summary risk of bias was rated as low for eight studies, moderate for nine, and high for nine studies (details in Table 2). All studies reported only on adults, except two studies based on the Canadian Community Health Survey (CCHS) [40, 47] which included those at least 12 years of age. Definitions of CRNA in surveys and the RCT generally included not filling a prescription or skipping doses because of the cost, while the health administrative database studies assumed that declines in utilization shortly after drug policy changes implied CRNA.

\section{Prevalence of medication CRNA in Canada}

Sixteen studies, excluding a medication-specific survey [49], addressed the prevalence of CRNA ( $n=105,109$ potential participants) (Table 1) [2, 3, 35-48]. Using somewhat differing definitions for CRNA and different sampling frames, these studies suggested a prevalence between 3.6 and $15.0 \%$ [2, 3, 35-48]. Ten of these studies providing more generalizable and population-level analyses (i.e., not highly selected sub-groups such as the homeless or those with several chronic conditions) based

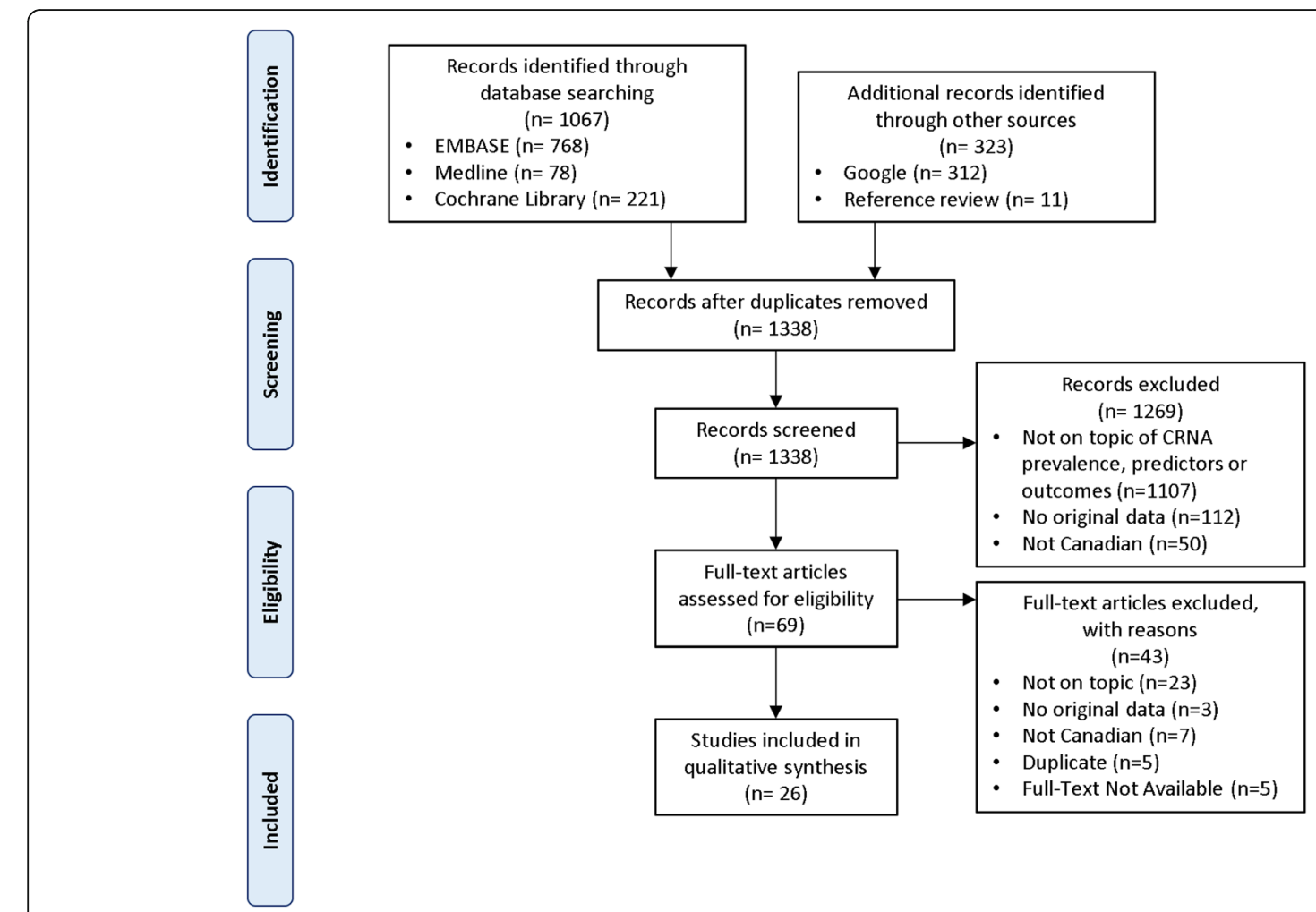

Fig. 1 Study flow chart 
Table 1 Study characteristics and results

\begin{tabular}{|c|c|c|c|c|c|}
\hline Study ID, design & Demographics & Definition of CRNA & $\begin{array}{l}\text { Prevalence } \\
\text { of CRNA }\end{array}$ & Predictors of CRNA ${ }^{a}$ & $\begin{array}{l}\text { Impact on } \\
\text { clinical outcomes }\end{array}$ \\
\hline $\begin{array}{l}\text { Brand } 1977 \text { [35] } \\
\text { Survey with in-person } \\
\text { interviews over a 3- } \\
\text { month period, year } \\
\text { unspecified }\end{array}$ & $\begin{array}{l}N=225 \text { patients } \\
\text { discharged from hospital } \\
\text { in Halifax, NS (mean } \\
\text { age 57.0) }\end{array}$ & $\begin{array}{l}\text { Not complying with } \geq 1 \\
\text { physician order(s) due to } \\
\text { cost of drugs }\end{array}$ & $13.8 \%$ & $\begin{array}{l}\text { "Cost of drugs" } \\
(p<0.001)\end{array}$ & N/A \\
\hline $\begin{array}{l}\text { Kennedy } 2006 \text { [36] } \\
\text { 2002-2003 Joint } \\
\text { Canada-US Survey } \\
\text { of Health }\end{array}$ & $\begin{array}{l}N=3505 \text { Canadian adults } \\
\geq 18 \text { years }\end{array}$ & $\begin{array}{l}\text { Failure to obtain a } \\
\text { prescribed medication } \\
\text { due to cost }\end{array}$ & $5.1 \%$ & No Canada-specific data & N/A \\
\hline $\begin{array}{l}\text { Hirth } 2008 \text { [37] } \\
\text { 2002-2004 DOPPS } \\
\text { patient questionnaires }\end{array}$ & $\begin{array}{l}N=503 \text { Canadian adult } \\
\text { hemodialysis patients } \\
\text { from } 20 \text { facilities (mean } \\
\text { age 62.1, SD 14.7) }\end{array}$ & $\begin{array}{l}\text { Not purchasing } \\
\text { medication due to cost }\end{array}$ & $12.9 \%$ & $\begin{array}{l}\text { Out-of-pocket spending } \\
\text { burden }\left(R^{2}=0.44\right)\end{array}$ & N/A \\
\hline $\begin{array}{l}\text { Kennedy } 2009 \text { [38] } \\
2007 \text { IHP phone } \\
\text { survey }\end{array}$ & $\begin{array}{l}N=2980 \text { Canadian adults } \\
\geq 18 \text { years }\end{array}$ & $\begin{array}{l}\text { Not filling a prescription } \\
\text { or skipping doses of } \\
\text { medication due to cost } \\
\text { during the previous } \\
12 \text { months }\end{array}$ & $8.0 \%$ & $\begin{array}{l}\text { Younger (<65 years), } \\
\text { multiple chronic } \\
\text { conditions, lower } \\
\text { household income, each } \\
p<0.01 \text { (OR not } \\
\text { reported); Quebec } \\
\text { (compulsory coverage) } \\
\text { compared to Ontario } \\
\text { (OR }=0.5,95 \% \text { Cl } 0.3-0.8 \text { ) }\end{array}$ & N/A \\
\hline $\begin{array}{l}\text { Kemp } 2010 \text { [39] } \\
2007 \text { IHP phone } \\
\text { survey }\end{array}$ & $\begin{array}{l}N=2183 \text { Canadian adults } \\
\geq 18 \text { years (median age } \\
50, \text { SE } 0.3 \text { ) }\end{array}$ & $\begin{array}{l}\text { Not filling a prescription } \\
\text { or skipping doses of } \\
\text { medication due to cost } \\
\text { during the previous } \\
12 \text { months }\end{array}$ & $8.0 \%$ & 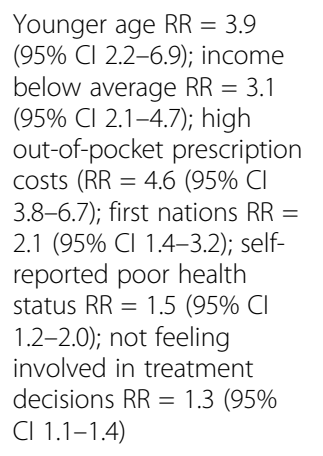 & N/A \\
\hline $\begin{array}{l}\text { Law } 2012 \text { [40] } \\
2007 \text { CCHS phone } \\
\text { survey }\end{array}$ & $\begin{array}{l}N=5732 \text { community- } \\
\text { dwelling Canadians } \geq 12 \\
\text { years who received a } \\
\text { prescription in the } \\
\text { previous year }\end{array}$ & $\begin{array}{l}\text { Altering a prescription to } \\
\text { make it last longer or not } \\
\text { filling a new prescription } \\
\text { or renewing an ongoing } \\
\text { prescription, due to cost }\end{array}$ & $\begin{array}{l}\text { Canadian sample, } \\
9.6 \%(95 \% \text { Cl 8.4- } \\
10.7 \%) ; \mathrm{QB}, 7.2 \% \\
(4.5-9.8) ; \mathrm{ON}, 9.1 \% \\
(7.2-11.0 \%) ; \mathrm{BC} \\
17.0 \%(12.6- \\
21.4 \%)\end{array}$ & $\begin{array}{l}\text { Younger age }(\mathrm{OR}=4.70 \text {, } \\
95 \% \mathrm{Cl} 2.91-7.60) ; \text { low } \\
\text { household income }(\mathrm{OR}= \\
3.29,95 \% \mathrm{Cl} 2.03-5.33) ; \\
\text { lack of insurance } \\
\text { coverage for drugs (OR = } \\
4.52,95 \% \mathrm{Cl} 3.29-6.20) ; \\
\text { several chronic health } \\
\text { conditions (OR = 1.61, } \\
95 \% \mathrm{Cl} 1.07-2.43) \text {; fair or } \\
\text { poor self-assessed health } \\
\text { status (OR = 2.64, 95\% Cl } \\
\text { 1.77-3.94); residing in } \mathrm{BC} \\
\text { (compared to Ontario) } \\
(\mathrm{OR}=2.56,95 \% \mathrm{Cl} \\
\text { 1.49-4.42) }\end{array}$ & N/A \\
\hline $\begin{array}{l}\text { Zheng } 2012 \text { [41] } \\
\text { Cross-sectional survey } \\
\text { with in-person } \\
\text { interviews between } \\
\text { March } 10 \text { and }\end{array}$ & $\begin{array}{l}N=60 \text { adult patients } \\
\text { attending a general } \\
\text { internal medicine rapid } \\
\text { assessment outpatient } \\
\text { clinic in Hamilton, ON }\end{array}$ & $\begin{array}{l}\text { Left prescriptions } \\
\text { unfilled, delayed filling } \\
\text { prescriptions, took } \\
\text { prescriptions with } \\
\text { reduced frequency or }\end{array}$ & $15.0 \%$ & $\begin{array}{l}\text { No drug insurance }(\mathrm{OR}= \\
20.7,95 \% \mathrm{Cl} 1.46-292.75) \\
\text { high out-of-pocket } \\
\text { expenses }(\mathrm{OR}=42.52 \\
95 \% \mathrm{Cl} 2.02-894.03)\end{array}$ & N/A \\
\hline
\end{tabular}


Table 1 Study characteristics and results (Continued)

\begin{tabular}{|c|c|c|}
\hline Study ID, design & Demographics & Definition of CRNA \\
\hline $\begin{array}{l}\text { Hunter } 2015 \text { [42] } \\
\text { HHiT study in-person } \\
\text { interviews between } \\
\text { January and } \\
\text { December } 2009\end{array}$ & $\begin{array}{l}N=716 \text { homeless or } \\
\text { vulnerably housed single } \\
\text { adults in Vancouver, } \\
\text { Toronto, and Ottawa and } \\
\text { prescribed } \geq 1 \text { current } \\
\text { medication }\end{array}$ & $\begin{array}{l}\text { Not actually taking a } \\
\text { current medication } \\
\text { prescribed by a doctor as } \\
\text { "the medication is too } \\
\text { expensive" }\end{array}$ \\
\hline $\begin{array}{l}\text { Hennessy } 2016 \text { [2] } \\
\text { BCPCHC survey } \\
\text { between February } \\
2011 \text { and March } 2012\end{array}$ & $\begin{array}{l}N=1849 \geq 40 \text { year from } \\
B C, A B, S K \text {, or MB who } \\
\text { reported having heart } \\
\text { disease, stroke, diabetes, } \\
\text { or hypertension (mean } \\
\text { age } 65.1,95 \% \mathrm{Cl} \\
64.3-65.9 \text { ) }\end{array}$ & $\begin{array}{l}\text { For the previous } 12 \\
\text { months, due to cost, } \\
\text { either (a) not getting } \\
\text { necessary prescription } \\
\text { medication or (b) } \\
\text { stopping one or more } \\
\text { prescribed drug for a } \\
\text { week or more }\end{array}$ \\
\hline $\begin{array}{l}\text { Lee } 2017 \text { [43] } \\
2014 \text { IHP phone } \\
\text { survey }\end{array}$ & $\begin{array}{l}N=4690 \text { community- } \\
\text { dwelling Canadians } \geq 55 \\
\text { years }\end{array}$ & $\begin{array}{l}\text { Not filling a prescription } \\
\text { or skipping doses within } \\
\text { the last } 12 \text { months } \\
\text { because of out-of-pocket } \\
\text { costs }\end{array}$ \\
\hline
\end{tabular}

\begin{tabular}{lll}
$\begin{array}{l}\text { Prevalence } \\
\text { of CRNA }\end{array}$ & Predictors of CRNA $^{\text {a }}$ & $\begin{array}{l}\text { Impact on } \\
\text { clinical outcomes }\end{array}$ \\
\hline $3.6 \%$ & N/A & N/A \\
& & \\
& &
\end{tabular}

4.1\% (95\% Cl
$2.6-6.3 \%)$
$8.3 \%$

\begin{abstract}
Morgan 2017 [3] 2014 IHP phone survey
\end{abstract}

Sarnak 2017 [44] OECD data, 2016 IHP phone survey and other sources

Soril 2017 [45] 2004-14 IHP phone surveys (selected years)

Law 2018 [46] 2016 CCHS phone survey

Laba 2018 [47] 2016 CCHS phone survey
$N=4696$ communitydwelling Canadians $\geq 55$ years

$N=4547$ Canadian adults
$\geq 18$ years

$N=28,091$ communitydwelling Canadians $\geq 12$ years

$N=8420$ communitydwelling Canadians $\geq 12$ years old with $\geq 2$ chronic conditions ot filling/collecting a prescription for medicine or skipped doses because of cost in the past 12 months

Not filling a prescription because of costs in the previous 12 months

Not filling a prescription or skipped doses within the last 12 months because of out-of-pocket costs

Skipping or reducing prescriptions or not filling prescriptions at all to reduce drug costs

Skipping or reducing dosages, delaying refill prescriptions, or not filling prescriptions at all to reduce drug costs dosages, or delaying refill
$8.3 \%$

Canadians (compared to the UK) (adjusted $\mathrm{OR}=$ 2.25, 95\% Cl 1.08-4.69); lower income (compared to UK) $(\mathrm{OR}=1.23,95 \% \mathrm{Cl}$ $0.64-2.40)$

Overall: 10.2\%; 0 N/A

N/A chronic diseases $5.0 \%$ vs. 1 chronic disease $12.0 \%$ vs. $2+$ chronic diseases $16.0 \%$

Overall: range 7.1- N/A

8.2\%; older/sicker adult cohort: range $6.5-19.8 \%$

$5.5 \%(95 \% \mathrm{Cl}$ $5.1-6.0 \%)$

Younger adult $(p<0.001) ; \quad$ N/A out-of-pocket prescription drug spending ( $p<$ 0.001 ); lack of drug insurance $(p<0.001)$; lower income $(p<0.001)$; poorer health status $(p<0.001)$

$10.2 \%(95 \% \mathrm{Cl}$ $8.6-11.9 \%) ; 15.2 \%$ (95\% Cl 11.6-18.8) for respiratory and $16.6 \%(95 \% \mathrm{Cl}$ 13.2-9.9\%) for mental health disorders

Age between 19 and 44 years (OR 2.74, 95\%Cl $1.76,4.26)$; out-of-pocket spending on prescription medicines > CAD500 OR 2.56, 95\% Cl 1.49, 4.40; lack of drug insurance (OR 3.26, 95\% Cl 2.12,
QC (compared to ON) (adjusted OR $=0.49$, 95\% Cl 0.29-0.82); younger age (compared to $\geq 65$ years): $55-64$ years $(\mathrm{OR}=$ 3.13, 95\% Cl 2.27-5.40); poor health status $(\mathrm{OR}=$ 1.75, 95\% Cl 1.12-2.38); low income $(\mathrm{OR}=3.59$, 95\% Cl 2.32-5.55); lack of private insurance $(\mathrm{OR}=$ 2.33, 95\% Cl 1.56-3.10)

N/A

N/A 4.80); fair to poor health status (OR 3.42, 95\% Cl $1.46,8.02)$; residing in certain provinces, e.g., BC (OR 4.20, 95\% Cl 2.55, 6.91) 
Table 1 Study characteristics and results (Continued)

\begin{tabular}{lll}
\hline Study ID, design & Demographics & Definition of CRNA \\
\hline Men 2019 [48] & $\begin{array}{l}N=11,172 \text { community- } \\
\text { dwelling Canadians with }\end{array}$ & $\begin{array}{l}\text { Skipping or reducing } \\
\text { dosages, delaying refill }\end{array}$ \\
survey & $\begin{array}{l}\text { a prescription within the } \\
\text { previous year and }\end{array}$ & $\begin{array}{l}\text { prescriptions, or not filling } \\
\text { answescriptions at all to } \\
\text { questionnaire }\end{array}$ \\
&
\end{tabular}

\section{Prevalence \\ of CRNA}

$8.3 \%$ (he questionnaire

Monagle 2018 [49] Phone survey of one anticoagulant clinic

Yao 2018 [50]

Retrospective pre-post database study 2005-

2009 pre- and post-

Seniors' Drug plan

policy change (max.

out-of-pocket \$15 per prescription for patients $\geq 65$ years) vs. concurrent control patients 40-64 years not affected by the policy

Dormuth 2006 [51]

Retrospective pre-post database study

between June 1997 and 2004 with

monthly time series

pre- (full coverage) vs.

post-policy

(copayment)

Schneeweiss

2007 [52]

Retrospective pre-post database study 2000-

2004 with repeated

measures design, monthly adherence measurement pre-

(full coverage) vs.

post-policy

(copayment)

\section{Schneeweiss}

2007 [53]

Retrospective pre-post database study 2000-

2004 with repeated measures design monthly adherence measurement pre(full coverage) vs. post-policy (copayment)
$N=110$ adult patients newly started on oral anticoagulants in Hamilton, ON

\section{$N=188,109$ observed} patients in SK adherence post-policy improved compared preperiod and to unaffected control

Leaving a prescription unfilled or delaying filling a prescription, or taking less of a medication, due to cost

Warfarin users were more likely to report CRN than NOAC users (40\% vs. $13 \%$, $p=0.02)$

$\mathrm{N} / \mathrm{A}$

Odds of optimal medication adherence: post-SDP (compared to pre-SDP) $(\mathrm{OR}=1.08,95 \%$ Cl 1.04 to 1.11 ), but only where OOP costs > \$15 per prescription, for prevalent users, for some medication classes. Not compared directly to concurrent control

$N=55,752 \mathrm{BC}$ residents $\geq$ 65 years not in a nursing home, dispensed inhaled corticosteroids (ICS) in 2001 (mean age 75.5) of respiratory inhalers declined after policy increasing out-of-pocket expenses

CRNA assumed if use of statins declined after policy increasing out-ofpocket expenses who were new users of statin drugs

$N=13,193$ seniors from $B C$ who were new users of $\beta$-blockers of beta-blockers declined after policy increasing out-of-pocket expenses
Initiation of ICS for a new diagnosis of asthma or COPD compared to prepolicy reduced by $25 \%$ (95\% Cl 14-31\%); discontinuation of ICS was increased $47 \%$ (40$55 \%$ ) in the copayment group

Paying 100\% out-ofpocket (compared to prepolicy) $(\mathrm{OR}=1.94,95 \% \mathrm{Cl}$ 1.82-2.08); patients postmyocardial infarction or post-revascularization (higher risk) $(\mathrm{OR}=0.63$, 95\% Cl 0.59-0.68)

N/A

Post-policy cohort N/A (compared to pre-policy) associated with a $1.3 \%$ decline in adherence (95\% Cl 2.5-0.04) pact on clinical outcomes

N/A

N/A

N/A

N/A

N/A 
Table 1 Study characteristics and results (Continued)

\begin{tabular}{|c|c|c|c|c|c|}
\hline Study ID, design & Demographics & Definition of CRNA & $\begin{array}{l}\text { Prevalence } \\
\text { of CRNA }\end{array}$ & Predictors of CRNA ${ }^{a}$ & $\begin{array}{l}\text { Impact on } \\
\text { clinical outcomes }\end{array}$ \\
\hline $\begin{array}{l}\text { Goldsmith } 2017 \text { [54] } \\
\text { Qualitative study with } \\
\text { semi-structured } \\
\text { interviews of CRNA } \\
\text { experience from } \\
\text { patients' perspective } \\
\text { 2014-2015 }\end{array}$ & $\begin{array}{l}N=35 \text { adults in } B C \text { and } \\
\text { ON who reported CRNA }\end{array}$ & $\begin{array}{l}\text { Patient self-report of } \\
\text { skipping doses, splitting } \\
\text { pills, or not filling their } \\
\text { prescriptions due to } \\
\text { out-of-pocket costs }\end{array}$ & $\mathrm{N} / \mathrm{A}$ & $\begin{array}{l}\text { Type of insurance; } \\
\text { individual's overall } \\
\text { financial flexibility; the } \\
\text { burden of drug cost on } \\
\text { the individual's budget; } \\
\text { perceived importance of } \\
\text { the drug }\end{array}$ & N/A \\
\hline $\begin{array}{l}\text { Gupta } 2019 \text { [55] } \\
\text { Qualitative study with } \\
\text { semi-structured } \\
\text { interviews of } \\
\text { strategies used to } \\
\text { deal with cost burden }\end{array}$ & $\begin{array}{l}N=12 \text { adult Canadians } \\
\text { with spinal cord injuries } \\
\text { who reported CRNA }\end{array}$ & N/A & N/A & $\begin{array}{l}\text { Out-of-pocket cost of } \\
\text { medication; perceived } \\
\text { importance of the drug; } \\
\text { lack of drug insurance; } \\
\text { competing financial } \\
\text { needs, e.g., food, housing; } \\
\text { inability to discuss with } \\
\text { physicians }\end{array}$ & N/A \\
\hline $\begin{array}{l}\text { Tamblyn } 2001 \text { [56] } \\
\text { Retrospective } \\
\text { database study with } \\
\text { interrupted monthly } \\
\text { time series 1993-1997 } \\
\text { pre (full coverage for } \\
\text { welfare and low- } \\
\text { income seniors; \$2 } \\
\text { copayment for all } \\
\text { other seniors) vs. }\end{array}$ & $\begin{array}{l}N=70,801 \text { elderly and } \\
25,820 \text { welfare recipients } \\
\text { using "essential drugs" in } \\
\text { QC }\end{array}$ & $\begin{array}{l}\text { CRNA assumed if post- } \\
\text { policy decrease in the } \\
\text { use of essential drugs }\end{array}$ & N/A & $\begin{array}{l}\text { Increase in cost sharing } \\
\text { associated with a } \\
\text { decrease in essential drug } \\
\text { use by elderly by } 9.1 \% \\
\text { ( } 95 \% \text { Cl } 8.7-9.6) \text { and by } \\
\text { welfare recipients by } \\
14.4 \%(95 \% \text { Cl 13.3- } \\
15.6 \%)\end{array}$ & $\begin{array}{l}\text { Net increase in } \\
\text { serious adverse } \\
\text { events by } 6.8 \text { and } \\
12.9 \text { per } 10,000 / \\
\text { month; in ED visits } \\
\text { by } 14.2 \text { and } 54.2 \\
\text { per } 10,000 / \text { month } \\
\text { for elderly and for } \\
\text { welfare recipients, } \\
\text { respectively }\end{array}$ \\
\hline
\end{tabular}

post-policy $(25 \%$

coinsurance and

deductible)

Pilote 2002 [57]

Retrospective

database study with

time-series analysis

1994-1998 pre- (full

coverage for welfare

and low-income

seniors and $\$ 2$

copayment for all

other seniors) vs.

post-policy $(25 \%$

coinsurance and

deductible)

Persaud $2019[58,59]$

Randomized open-

label trial 2016-2017

with free access

including free delivery

of prescribed essential

medication,

compared to

usual care
$N=22,066$ patients $\geq 65$ years admitted to a QC hospital for a first acute myocardial infarction and discharged alive
CRNA assumed if the proportion of patients who filled at least one prescription during the year after discharge declined post-policy change
N/A

N/A as no change in adherence pre- vs. post-policy

No variation in adherence by income
No differences in readmission for cardiac complications, mortality rate, or use of outpatient physician or ED services
$N=786$ adults $\geq 18$ years old in 9 primary care practices in ON who reported CRNA (mean age 51.7 years, $55.9 \%$ female)
Self-reported not filling a prescription or making a prescription last longer because of the cost within the previous 12 months
N/A

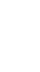

No difference in rates of hospitalization, serious adverse events, or deaths

CRNA cost-related nonadherence, N/A data not available, BCPCHC barriers to care for people with chronic health conditions, DOPPS Dialysis Outcomes and Practice Patterns Study, HHiT health and housing in transition, IHP International Health Policy, CCHS Canadian Community Health Survey, OECD Organization for Economic Co-operation and Development, ICS inhaled corticosteroids, SDP Seniors' Drug Plan, BC British Columbia, AB Alberta, SK Saskatchewan, MB Manitoba, ON Ontario, QC Quebec, NNT number needed to treat

aUsing adjusted or multivariable analyses

on large national or international surveys suggested rates of 5.1 to $10.2 \%[3,36,38-40,43-46,48]$. The Joint Canada-US Survey of Health telephone survey in 2002 included 3505 Canadian adults, 5.1\% of whom reported CRNA [36]. In the International Health Policy telephone surveys, $8.0 \%$ of the sampled Canadian adults reported CRNA in 2007 and $10.2 \%$ in 2016 [38, 39, 44]. The
CRNA section of the Canadian Community Health Surveys (CCHS) found that $9.6 \%$ of adults who received a prescription reported CRNA in 2007 compared to 5.5\% overall in 2016 [40, 46]. The 2007 analysis suggested geographic variability, with higher rates of CRNA in British Columbia than other regions [46]. Two studies examined different sub-groups of the 2016 CCHS [47, 48]. Two 
Table 2 Summary risk of bias ratings

\begin{tabular}{|c|c|c|c|c|c|c|c|c|c|c|c|}
\hline \multirow{2}{*}{$\begin{array}{l}\text { Randomized Controlled } \\
\text { Study }^{\mathrm{a}}\end{array}$} & \multicolumn{10}{|c|}{ Risk of Bias Domain } & \multirow{2}{*}{$\begin{array}{c}\text { Summary } \\
\text { Rating }\end{array}$} \\
\hline & 1 & 2 & 3 & 4 & 5 & 6 & 7 & & & & \\
\hline Persaud 2019(58) & $\odot$ & $\odot$ & e & $\odot$ & $\theta$ & $\odot$ & 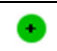 & & & & $\odot$ \\
\hline \multirow[t]{2}{*}{ Qualitative $^{\mathrm{b}}$} & \multicolumn{10}{|c|}{ Risk of Bias Domain } & $\begin{array}{c}\text { Summary } \\
\text { Rating }\end{array}$ \\
\hline & 1 & 2 & 3 & 4 & 5 & 6 & 7 & 8 & 9 & 10 & \\
\hline Goldsmith 2017(51) & $\odot$ & $\odot$ & $\odot$ & $\odot$ & $\odot$ & $\odot$ & $\odot$ & $\odot$ & $\odot$ & $\odot$ & $\odot$ \\
\hline Gupta 2019(57) & $\odot$ & $\odot$ & $\odot$ & $\theta$ & $\odot$ & $\Theta$ & $\odot$ & $\odot$ & + & $\odot$ & $\odot$ \\
\hline \multirow{2}{*}{ Pre-Post Time Series ${ }^{c}$} & \multicolumn{10}{|c|}{ Risk of Bias Domain } & $\begin{array}{c}\text { Summary } \\
\text { Rating }\end{array}$ \\
\hline & 1 & 2 & 3 & 4 & 5 & 6 & 7 & & & & \\
\hline Dormuth 2006(48) & ○ & $\odot$ & $\odot$ & $\odot$ & $\odot$ & $\odot$ & $\odot$ & & & & $+\%$ \\
\hline Pilote 2002(53) & $\odot$ & $\odot$ & 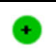 & $\theta$ & $\odot$ & + & $\odot$ & & & & $\odot$ \\
\hline $\begin{array}{l}\text { Schneeweiss (Beta) } \\
2007(50)\end{array}$ & $\odot$ & $\odot$ & $\odot$ & $\Theta$ & $\odot$ & $\odot$ & $\odot$ & & & & $\odot$ \\
\hline $\begin{array}{l}\text { Schneeweiss (Statin) } \\
2007(49)\end{array}$ & $\odot$ & $\odot$ & $\odot$ & 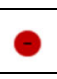 & $\odot$ & $\odot$ & $\odot$ & & & & $\odot$ \\
\hline Tamblyn 2001(52) & $\odot$ & $\odot$ & $\odot$ & $\ominus$ & $\odot$ & $\odot$ & $\odot$ & & & & $\odot$ \\
\hline $\begin{array}{l}\text { Yao 2018(47) (pre-post } \\
\text { only) }\end{array}$ & $\odot$ & $\odot$ & 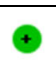 & $\odot$ & $\ominus$ & $\ominus$ & $\ominus$ & & & & +1. \\
\hline \multirow[t]{2}{*}{ Survey $^{d}$} & \multicolumn{10}{|c|}{ Risk of Bias Domain } & $\begin{array}{c}\text { Summary } \\
\text { Rating }\end{array}$ \\
\hline & 1 & 2 & 3 & 4 & 5 & & & & & & \\
\hline Brand 1977(35) & $\ominus$ & 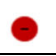 & $\theta$ & $\theta$ & $\odot$ & & & & & & 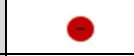 \\
\hline Hennessy 2016(2) & $\theta$ & $\odot$ & $\theta$ & $\theta$ & $\theta$ & & & & & & ○ \\
\hline Hirth 2008(37) & + & $\odot$ & $\odot$ & $\theta$ & $\theta$ & & & & & & +1. \\
\hline Hunter 2015(42) & 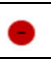 & $\theta$ & $\theta$ & $\odot$ & $\odot$ & & & & & & +1. \\
\hline Kemp 2010(39) & $\ominus$ & $\odot$ & 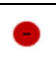 & $\theta$ & $\odot$ & & & & & & $\ominus$ \\
\hline Kennedy 2006(36) & ? & $\odot$ & $\odot$ & $\theta$ & $\odot$ & & & & & & 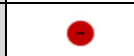 \\
\hline Kennedy 2009(38) & $\ominus$ & 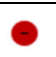 & $\theta$ & $\theta$ & $\odot$ & & & & & & $\ominus$ \\
\hline Laba 2018(54) & 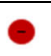 & + & + & $\theta$ & $\odot$ & & & & & & +1. \\
\hline Law 2012(40) & ? & 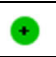 & + & $\theta$ & $\odot$ & & & & & & +1. \\
\hline Law 2018(46) & $\odot$ & $\odot$ & + & $\odot$ & $\odot$ & & & & & & $\odot$ \\
\hline Lee 2017(43) & ? & $\theta$ & $\odot$ & $\odot$ & 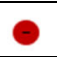 & & & & & & +1. \\
\hline Men 2019 (55) & $\ominus$ & $\odot$ & + & 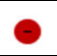 & $\theta$ & & & & & & +1. \\
\hline Morgan 2017(3) & ? & ○ & $\theta$ & $\theta$ & $\theta$ & & & & & & $\theta$ \\
\hline Monagle 2018 (56) & 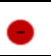 & $\odot$ & + & 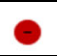 & $\odot$ & & & & & & +1. \\
\hline Sarnak 2017(44) & $\theta$ & $\theta$ & + & $\theta$ & $\theta$ & & & & & & $\theta$ \\
\hline Soril 2017(45) & ? & 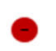 & $\theta$ & $\theta$ & $\theta$ & & & & & & $\theta$ \\
\hline Zheng 2012(41) & ? & $\theta$ & $\theta$ & $\odot$ & $\ominus$ & & & & & & $\theta$ \\
\hline
\end{tabular}

${ }^{\mathrm{a}} \mathrm{RoB}$ domains for randomized controlled studies ( 1 = random sequence generation; 2 = allocation concealment; 3 = blinded participants and providers; 4 = blinded outcome assessors; $5=$ incomplete outcome data; $6=$ selective reporting; $7=$ other biases)

${ }^{\mathrm{b}} \mathrm{RoB}$ domains for qualitative studies ( 1 = clear statement of aims; $2=$ qualitative methods justified; $3=$ appropriate design for research aims; $4=$ appropriate recruitment strategy; $5=$ confidence in data collection; $6=$ personal biases; $7=$ ethical considerations; $8=$ confidence in data analysis; $9=$ clear statement of findings; $10=$ value of research)

${ }^{\mathrm{C}} \mathrm{RoB}$ domains for pre-post time series studies ( 1 = confounding variables/events; 2 = analysis at point of intervention; $3=$ intervention effects on data collection; 4 $=$ blinding or objective outcomes; $5=$ effect of missing outcome measures; $6=$ selective reporting; $7=$ other biases)

${ }^{d}$ RoB domains for surveys ( 1 = representativeness of sample; 2 = adequacy of response rate; $3=$ missing data; $4=$ pilot testing; $5=$ published validity of survey instrument). (-) denotes a high risk of bias, +\% denotes a moderate risk of bias, and + denotes a low risk of bias) 
additional studies estimated CRNA in specific sub-groups groups of Canadian patients, and reported rates of $10.2 \%$ in Canadians with comorbidities and $8.3 \%$ in participants with food insecurity $[37,41]$.

\section{Predictors of CRNA}

Nineteen studies ( $n=440,064$ potential participants) provided information on the predictors of CRNA (details in Table 1) [2, 3, 35, 37-41, 43, 46-48, 50-56, 58]. Thirteen studies $(n=70,636)$ analyzed multiple potential factors based on direct reporting from study participants $[2,3,35,37-41,43,46-48,54]$. Five additional studies ( $n=369,416)$ involving large administrative databases used time-series methods with or without pre-post analyses of policies which changed the amount of patient cost-sharing in provinces, to suggest that increased outof-pocket expenditures for drugs is a predictor of nonadherence assumed to be CRNA [50-53, 56].

Several factors emerged as independent predictors in the studies using multivariable analyses. In order of high to low frequency of mention, these were high out-ofpocket expenses on medication, lower household income or financial flexibility, lack of drug insurance, younger age, poor self-reported health, province of residence, and miscellaneous (Table 3) [2, 3, 35-41, 43, 46-48, 50-57]. The analysis of the CRNA module within the 2007 CCHS was the largest and most detailed, showing a prevalence of $11.4 \%$ for the 35 to 44 years age group compared to $4.8 \%$ for subjects older than 65 years [40]. In the multivariable analysis, odds ratios were 4.5 for the lack of drug insurance, 3.3 for low household income. $20.1 \%$ of participants reporting poor health also reported CRNA compared to $10.4 \%$ of subjects reporting good health (OR 2.64, 95\% CI 1.77-3.94) [40]. Finally, factors which may reflect differences among jurisdictions including their policies, were also independent predictors.
Among those younger than 65 years, respondents in the 2014 International Health Policy Survey (IHPS) who were from Quebec were less likely to report CRNA than those residing in Ontario (OR 0.5, 95\% CI 0.3-0.8) [43]. At the time, while drug insurance was compulsory in Quebec, Ontario, reimbursed non-seniors only for those who were socially disadvantaged or had very high medication costs [43]. In the 2007 CCHS, residence in British Columbia where a significant portion of public drug coverage has income-based deductibles was associated with more CRNA compared with Ontario (OR 2.56, 95\% CI 1.49-4.42) [40]. The IHPS segment of Canadians selfidentifying as First Nations, Inuit or Metis, were at higher risk of CRNA (RR 2.1, 95\% CI 1.4-3.2) [39]. Although the publicly funded Non-insured Health Benefits Program includes drug benefits without copayment or deductible, these apply only to those considered "status Indians" or Inuk and require providers to register with the program to avoid initial self-pay [60].

Three studies in $\mathrm{BC}$ using a similar cohort with similar methodology examined the influence of increased outof-pocket expense by analyzing the effect of changes in drug insurance coverage on adherence measured by prescription dispensing intervals [51-53]. The utilization of maintenance respiratory inhalers declined by approximately 5.8 to $12.3 \%(p<0.001)$, the rate of full adherence to statins decreased by $5.4 \%$ (95\% CI, 6.4 to $4.4 \%$ ), but adherence to beta-blockers was only modestly reduced (approximately 1\%) compared to full coverage [51-53]. Nonadherence was associated with higher outof-pocket expenditures, with beta-blockers thought to be less affected because of their low cost compared to the other drug groups at the time of the study [53]. For statins, adherence was better in high-risk patients with prior vascular events compared to the entire group [52]. An analysis of a policy change to lower seniors' out-of-

Table 3 Predictors of CRNA in Canada

\begin{tabular}{lll}
\hline Predictor & $\begin{array}{l}\text { No. of articles reporting } \\
\text { significance }\end{array}$ & Citations \\
\hline Higher out-of-pocket costs ${ }^{\text {a }}$ & 13 & {$[2,3,37,39-41,47,50-53,55,56]$} \\
Lower income or low financial flexibility & 9 & {$[3,38-40,43,46,48,54,55]$} \\
Lack of drug insurance & 7 & {$[40,41,43,46,47,54,55]$} \\
Younger age & 6 & {$[38-40,43,46,47]$} \\
Poor self-reported health status & 5 & {$[39,40,43,46,47]$} \\
Province of residence (e.g., Ontario instead of Quebec, or & 4 & {$[38,43,46,47]$} \\
British Columbia instead of Ontario or Quebec) & 2 & {$[38,46]$} \\
Several chronic health conditions & 2 & {$[35,54]$} \\
High cost of drugs & 2 & {$[54,55]$} \\
Low/medium drug importance from individual's perspective & 2 & {$[39,55]$} \\
Not feeling involved in treatment decisions & 1 & {$[39]$} \\
First Nations status & 2 &
\end{tabular}

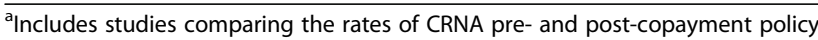


pocket prescription drug costs in Saskatchewan in 2007, found a small increase in optimal medication adherence after the policy change [50].

CRNA association with clinical outcomes Only three studies measured clinical outcomes potentially related to CRNA (Table $1 ; n=93,653$ ) [56-58]. The highest quality study was a recent randomized controlled trial involving patients in primary care in Ontario who reported that they did not fill a prescription or changed regimens to make their supply last longer because of the cost. The study found that the intervention group provided free, mailed prescriptions deemed essential, reported better adherence, improved perceived care, and less concern about making ends meet at 12 months follow-up. Several surrogate outcomes were followed, with improvement in blood pressure in the intervention group for those requiring antihypertensives but no significant improvement in $\mathrm{A} 1 \mathrm{C}$ or cholesterol. However, there was no difference in hospitalizations, serious adverse events, or death.

The introduction of a drug policy in Quebec in the nineties increased out-of-pocket costs for all residents. In one retrospective study, this led to a decrease in the overall number of drugs used per day by the elderly and by welfare recipients, including "essential" medications such as aspirin and furosemide (decrease of 9.1-14.4\%) as well as symptomatic but potentially harmful drugs such as benzodiazepines (decrease of 15.1-22.4\%). The decline in the use of essential drugs was associated with a small increase in serious adverse events including death, hospital or nursing home admission, or emergency department visits [56]. In a second retrospective study, there was no change in adherence to post-myocardial infarction medication adherence and no change in clinical outcomes after the policy compared to pre-policy [57].

\section{Discussion}

We believe that this is the first systematic review to focus on the relationship between medication costs and medication adherence in Canada. All but one of the studies in our review were observational therefore susceptible to bias and confounders. We found rates of CRNA range from 5.1 to $10.2 \%$ in general surveys of the population over time, suggesting that an important minority of the population is experiencing problems with prescription medication adherence due to their medication cost. The range is likely explained by differing sampling frames, questions, definitions of CRNA, and statistical uncertainty. The international studies in our review suggest that Canadian rates of CRNA are in the middle of other developed countries. In the IHPS survey, the rate of CRNA in Canada (8\%) was in the middle of seven countries, with the Netherlands having the lowest rate $(3 \%)$ and the USA having the highest rate $(20 \%)$
[39]. In the dialysis study, the rate of CRNA in Canada (12.9\%) was similar to the overall rate of CRNA among 12 countries (13.4\%), with Japan being the lowest rate (3.2\%) and the USA being the highest rate (29.2\%) [38].

Overall, predictors for CRNA in Canada revolved around lack of affordability, younger age, chronic illness, private insurance coverage, and province of residence. This likely reflects the characteristics of the different public drug plan coverage programs and different financial capability to afford medicines in different provinces. None of the studies developed or used a clinical prediction rule, which would examine the risk factors together to determine how their quantitative combination influences risk [61]. This is a well-established method to refine population risk to individual risk. Both qualitative studies found that patients weighed their financial obligations against the perceived importance of the medications in making their adherence decisions and recognized that they sometimes were making decisions that might adversely affect their health [54].

The lack of current information on the association of CRNA with clinical outcomes in Canada is very troubling, as this is the primary question of interest both for clinicians and policymakers. Although low adherence to beneficial medications has previously been linked to increased mortality, the data may be biased due to the "healthy user" effect [17]. Randomized trials show that interventions to improve adherence do so only modestly and do not seem to improve patient outcomes [62]. Two recent randomized controlled trials (RCTs) in the USA directly address whether removing medication cost improves clinical outcomes. The aforementioned MI FREEE RCT found that free coverage for essential cardiovascular medications post-myocardial infarction increased adherence by 4 to $6 \%(p<0.001)$ but did not improve the primary outcome of the first major vascular event or procedure [20]. More recently, the ARTEMIS trial also found that provision of free access to $\mathrm{P}_{2} \mathrm{Y}_{12}$ inhibiting anti-platelet agents for a year increased adherence by a small amount (2.3\%), but there was no difference in major adverse cardiovascular events [63]. In addition, since patients are frequently taking medications that are not essential and may be harmful, decreased adherence to these medications may not lead to adverse outcomes. Two of our studies suggested that participants reported increased health care utilization as a result of their CRNA, but did not actually measure clinical outcomes or healthcare utilization $[46,55]$. The sole RCT in our SR found that the free provision and delivery of essential medications increased adherence by $10 \%$ and improved one of three clinical surrogates at 12 months follow-up, but did not improve clinical outcomes [58]. In summary, the relationship between medication costs, medication adherence, and patient outcomes is more complex than originally thought. 
This systematic review has limitations worth noting. First, since studies varied in their methods of measurement, quantitative pooling was not possible. Second, there is no gold standard measure for medication adherence, so there are likely measurement errors with each of the methods used. Third, questionnaire studies are susceptible to responder and recall bias, and the studies examining adherence before and after policy changes are somewhat indirect inferences regarding the impact of costs. Fourth, we were unable to find information on how different types of insurance-co-pays, deductibles, annual maximums, etc.-influence the prevalence of CRNA. Finally, since multiple behavioral attributes are associated with nonadherence, it would take a very large prospective study to determine the specific impact of medication cost on adherence.

The findings of this systematic review have several implications. First, as CRNA may affect a large number of Canadians, communication between providers and patients regarding affordability of prescribed medications is essential and may play an important role in the reduction of CRNA. Second, the evidence summarized here will be useful to inform the debate on a national PharmaCare program where proponents cite estimates of higher health care utilization because of the patient burden of medication costs while opponents cite the lack of evidence that removal of patient-borne costs improves outcomes [64, 65]. Modeling of a universal drug benefit program would benefit from better estimates of the impact of CRNA on health care utilization and clinical outcomes [28]. The association of high out-of-pocket medication costs with lower adherence might argue for improved drug coverage for those with low incomes. However, the high-quality evidence so far suggests that more research is required to determine for which people, which drugs, which situations, and how much cost relief might be required to improve clinical outcomes

\section{Conclusion}

Our systematic review suggests that an important minority of Canadians may not be adherent to medications because of their costs. Financial factors appear to be the main predictors of CRNA, suggesting that drug program design and coverage have a significant influence on CRNA rates. However, consistent with international evidence to date, removal of all medication cost for essential drugs for patients with CRNA has not been shown to improve clinical outcomes.

\section{Supplementary Information}

The online version contains supplementary material available at https://doi. org/10.1186/s13643-020-01558-5.

Additional file 1. PRISMA 2009 Checklist for CRN SR Canada.

Additional file 2. Appendix. MEDLINE Search Strategy.

\section{Abbreviations}

CRNA: Cost-related nonadherence; ED: Emergency department;

CCHS: Canadian Community Health Survey; IHPS: International Health Policy Survey

\section{Acknowledgements \\ Not applicable.}

\section{Authors' contributions}

$\mathrm{AH}$ was responsible for the conception and design of the work. $\mathrm{AH}, \mathrm{MW}, \mathrm{ML}$, $\mathrm{NC}, \mathrm{LN}, \mathrm{MG}, \mathrm{SM}$, and AF contributed to the acquisition and analysis of the data. All authors contributed to the interpretation of the data. $\mathrm{AH}$ wrote each draft and the final manuscript. All authors contributed to the revisions of the drafts. The authors read and approved the final manuscript.

\section{Funding}

Funded by the Canadian Institutes of Health Research (CIHR) Grant MOP126020, Principal Investigator Dr. Michael Law and CIHR Grant FRN-148803, and Principal Investigator Dr. Anne Holbrook. Dr. Law received salary support through a Canada Research Chair and a Michael Smith Foundation for Health Research Scholar Award.

\section{Availability of data and materials}

All data generated or analyzed during this study are included in this published article and its supplementary information files.

Ethics approval and consent to participate

Not applicable.

\section{Consent for publication}

Not applicable.

\section{Competing interests}

Michael Law has consulted for Health Canada and the Health Employees' Union and provided expert witness testimony for the Attorney General of Canada. Anne Holbrook has served as an expert policy advisor for national, provincial, and local hospital public drug plans for several decades. All other authors report no relevant competing interests.

\section{Author details}

${ }^{1}$ Division of Clinical Pharmacology \& Toxicology, Department of Medicine, McMaster University, Hamilton, ON, Canada. ${ }^{2}$ Department of Health Research Methods, Evidence and Impact, McMaster University, Hamilton, ON, Canada.

${ }^{3}$ Schulich School of Medicine \& Dentistry, Western University, London, ON, Canada. ${ }^{4}$ Bachelor of Health Studies Program, University of Waterloo, Waterloo, ON, Canada. ${ }^{5}$ Bachelor of Health Sciences Program, McMaster University, Hamilton, ON, Canada. ${ }^{6}$ School of Medicine, Queen's University, Kingston, ON, Canada. ${ }^{7}$ Global Health Program, McMaster University, Hamilton, ON, Canada. ${ }^{8}$ The Centre for Health Services and Policy Research, School of Population and Public Health, The University of British Columbia, Vancouver, BC, Canada.

Received: 6 May 2020 Accepted: 15 December 2020

Published online: 06 January 2021

References

1. Briesacher BA, Gurwitz JH, Soumerai SB. Patients at-risk for cost-related medication nonadherence: a review of the literature. J Gen Intern Med. 2007;22(6):864-71.

2. Hennessy DA, Sanmartin C, Ronksley P, Weaver R, Campbell D, Manns B, et al. Out-of-pocket spending on drugs and pharmaceutical products and cost-related prescription non-adherence among Canadians with chronic disease. Ottawa: Statistics Canada; 2016.

3. Morgan SG, Lee A. Cost-related non-adherence to prescribed medicines among older adults: a cross-sectional analysis of a survey in 11 developed countries. BMJ Open. 2017;7(1):e014287.

4. Naci H, Soumerai SB, Ross-Degnan D, Zhang F, Briesacher BA, Gurwitz JH, et al. Medication affordability gains following Medicare Part $D$ are eroding among elderly with multiple chronic conditions. Health Affairs. 2014;33(8): 1435-43. 
5. Lee M, Salloum RG. Racial and ethnic disparities in cost-related medication non-adherence among cancer survivors. J Cancer Surviv Res Pract. 2016。 10(3):534-44.

6. Harrold LR, Briesacher BA, Peterson D, Beard A, Madden J, Zhang F, et al. Cost-related medication nonadherence in older patients with rheumatoid arthritis. J Rheumatol. 2013:40(2):137-43.

7. Marcum ZA, Zheng Y, Perera S, Strotmeyer E, Newman AB, Simonsick EM, et al. Prevalence and correlates of self-reported medication non-adherence among older adults with coronary heart disease, diabetes mellitus, and/or hypertension. Res Soc Adm Pharm. 2013;9(6):817-27.

8. Goldman DP, Joyce GF, Zheng Y. Prescription drug cost sharing: associations with medication and medical utilization and spending and health. J Am Med Assoc. 2007;298(1):61-9.

9. Mindaugas S, SJ FJ, Eija V, Gabriella MM, Örjan S, Francisco TG, et al. Factors associated with refraining from buying prescribed medications among older people in Europe. Aust J Ageing. 2014;33(4):E25-30.

10. Leung VC, Jin YP, Hatch W, Mammo Z, Trope GE, Buys YM, et al. The relationship between sociodemographic factors and persistence with topical glaucoma medications. J Glaucoma. 2015;24(1):69-76.

11. Levesque A, Li HZ, Pahal JS. Factors related to patients' adherence to medication and lifestyle change recommendations: data from Canada. Int J Psychol Stud. 2012;4:42.

12. Lummis HL, Sketris IS, Gubitz GJ, Joffres MR, Flowerdew GJ. Medication persistence rates and factors associated with persistence in patients following stroke: a cohort study. BMC Neurol. 2008;8(no pagination):25.

13. Gourzoulidis G, Kourlaba G, Stafylas P, Giamouzis G, Parissis J, Maniadakis N. Association between copayment, medication adherence and outcomes in the management of patients with diabetes and heart failure. Health Policy. 2017;121(4):363-77.

14. Mikyas Y, Agodoa I, Yurgin N. A systematic review of osteoporosis medication adherence and osteoporosis-related fracture costs in men. Appl Health Econ Health Policy. 2014;12(3):267-77.

15. Blanchard J, Madden JM, Ross-Degnan D, Gresenz CR, Soumerai SB. The relationship between emergency department use and cost-related medication nonadherence among Medicare beneficiaries. Ann Emerg Med. 2013;62(5):475-85.

16. Lieberman DA, Polinski JM, Choudhry NK, Avorn J, Fischer MA. Medicaid prescription limits: policy trends and comparative impact on utilization. BMC Health Serv Res. 2016;16:15.

17. Simpson SH, Eurich DT, Majumdar SR, Padwal RS, Tsuyuki RT, Varney J, et al. A meta-analysis of the association between adherence to drug therapy and mortality. Br Med J. 2006;333(7557):15-8.

18. Sokol MC, McGuigan KA, Verbrugge RR, Epstein RS. Impact of medication adherence on hospitalization risk and healthcare cost. Med Care. 2005;43(6): 521-30.

19. McGrady ME, Hommel KA. Medication adherence and health care utilization in pediatric chronic illness: a systematic review. Pediatrics. 2013;132(4):730-40.

20. Choudhry NK, Avorn J, Glynn RJ, Antman EM, Schneeweiss S, Toscano M, et al. Full coverage for preventive medications after myocardial infarction. $N$ Engl J Med. 2011;365(22):2088-97.

21. Atella V, Schafheutle E, Noyce P, Hassell K. Affordability of medicines and patients' cost-reducing behaviour: empirical evidence based on SUR estimates from Italy and the UK. Appl Health Econ Health Policy. 2005;4(1):23-35.

22. Schafheutle El, Hassell K, Noyce PR, Weiss MC. Access to medicines: cost as an influence on the views and behaviour of patients. Health Soc Care Community. 2002;10(3):187-95.

23. Davidova J, Ivanovic N, Praznovcova L. Participation in pharmaceutical costs and seniors' access to medicines in the Czech Republic. Cent Eur J Public Health. 2008;16(1):26-8

24. CIHI. National health expenditure trends, 1975 to 2017. www.cihi.ca2017 [cited 2018. Available from: https://www.cihi.ca/sites/default/files/document/ nhex2017-trends-report-en.pdf

25. Clement F, Memedovich KA. Drug coverage in Canada: gaps and opportunities. J Psychiatry Neurosci. 2018:43(3):148

26. Gagnon M-A. The role and impact of cost-sharing mechanisms for prescription drug coverage. CMAJ. 2017;189(19):E680-E1.

27. Morgan SG, Gagnon M-A, Mintzes B, Lexchin J. A better prescription: advice for a national strategy on pharmaceutical policy in Canada. Healthc Policy. 2016;12(1):18.

28. Morgan SG, Law M, Daw JR, Abraham L, Martin D. Estimated cost of universal public coverage of prescription drugs in Canada. CMAJ. 2015; 187(7):491-7.
29. Moher D, Liberati A, Tetzlaff J, Altman DG. Preferred reporting items for systematic reviews and meta-analyses: the PRISMA statement. Ann Intern Med. 2009;151(4):264-9.

30. Liberati A, Altman DG, Tetzlaff J, Mulrow C, Gøtzsche PC, loannidis JP, et al. The PRISMA statement for reporting systematic reviews and meta-analyses of studies that evaluate health care interventions: explanation and elaboration. Ann Intern Med. 2009;151(4):W-65-94.

31. Agarwal A, Guyatt GH, Busse JW. Methods commentary: risk of bias in crosssectional surveys of attitudes and practices 2017 Available from: https:// www.evidencepartners.com/resources/methodological-resources/risk-ofbias-cross-sectional-surveys-of-attitudes-and-practices/.

32. Critical Appraisal Skills Programme. CASP Checklist: 10 questions to help you make sense of a qualitative research. 2018 cited 2018. Available from: https:/ casp-uk.net/wp-content/uploads/2018/01/CASP-Qualitative-Checklist.pdf.

33. Cochrane Effective Practice and Organisation of Care (EPOC). Suggested risk of bias criteria for EPOC reviews. 2017 Available from: https://epoc.cochrane. org/sites/epoc.cochrane.org/files/public/uploads/Resources-for-authors2017/ suggested_risk_of_bias_criteria_for_epoc_reviews.pdf.

34. Cochrane Handbook for Systematic Reviews of Interventions Version 5.1.0. Summary assessments of risk of bias 2011 Available from: https:// handbook-5-1.cochrane.org/index.htm\#chapter_8/8_7_summary_ assessments_of_risk_of_bias.htm.

35. Brand FN, Smith RT, Brand PA. Effect of economic barriers to medical care on patients' noncompliance. Public Health Rep. 1977;92(1):72-8.

36. Kennedy J, Morgan S. A cross-national study of prescription nonadherence due to cost: data from the joint Canada-United States survey of health. Clin Ther. 2006;28(8):1217-24.

37. Hirth RA, Greer SL, Albert JM, Young EW, Piette JD. Out-of-pocket spending and medication adherence among dialysis patients in twelve countries. Health Aff. 2008;27(1):89-102.

38. Kennedy J, Morgan S. Cost-related prescription nonadherence in the United States and Canada: a system-level comparison using the 2007 international health policy survey in seven countries. Clin Ther. 2009;31(1):213-9.

39. Kemp A, Roughead E, Preen D, Glover J, Semmens J. Determinants of selfreported medicine underuse due to cost: a comparison of seven countries. J Health Serv Res Policy. 2010;15(2):106-14.

40. Law MR, Cheng L, Dhalla IA, Heard D, Morgan SG. The effect of cost on adherence to prescription medications in Canada. CMAJ. 2012;184(3):297-302.

41. Zheng B, Poulose A, Fulford M, Holbrook A. A pilot study on cost-related medication nonadherence in Ontario. J Popul Ther Clin Pharmacol. 2012; 19(2):e239-e47.

42. Hunter CE, Palepu A, Farrell S, Gogosis E, O'Brien K, Hwang SW. Barriers to prescription medication adherence among homeless and vulnerably housed adults in three Canadian cities. J Prim Care Community Health. 2015;6(3):154-61.

43. Lee A, Morgan S. Cost-related nonadherence to prescribed medicines among older Canadians in 2014: a cross-sectional analysis of a telephone survey. CMAJ Open. 2017;5(1):E40-E4

44. Sarnak DO, Squires D, Kuzmak G, Bishop S. Paying for prescription drugs around the world: why is the U.S. an outlier? Issue Brief. 2017:2017:1-14.

45. LJJ S, Adams T, Phipps-Taylor M, Winblad U, Clement F. Is Canadian healthcare affordable? A comparative analysis of the Canadian healthcare system from 2004 to 2014. Healthcare Policy. 2017;13(1):43-58.

46. Law MR, Cheng L, Kolhatkar A, Goldsmith L, Morgan SG, Holbrook AM, et al. The consequences of patient charges for prescription drugs in Canada: a cross-sectional survey. CMAJ Open. 2018;6(1):E63-70.

47. Laba T-L, Cheng L, Kolhatkar A, Law MR. Cost-related nonadherence to medicines in people with multiple chronic conditions. Res Soc Adm Pharm. 2020;16(3):415-21.

48. Men F, Gundersen C, Urquia ML, Tarasuk V. Prescription medication nonadherence associated with food insecurity: a population-based crosssectional study. CMAJ open. 2019;7(3):E590-E7.

49. Monagle SR, Hirsh J, Bhagirath VC, Ginsberg JS, Bosch J, Kruger P, et al. Impact of cost on use of non-vitamin $\mathrm{K}$ antagonists in atrial fibrillation patients in Ontario, Canada. J Thromb Thrombolysis. 2018;46(3):310-5.

50. Yao S, Lix L, Shevchuk Y, Teare G, Blackburn DF. Reduced out-of-pocket costs and medication adherence - a population-based study. J Popul Ther Clin Pharmacol. 2018;25(1):e1-e17.

51. Dormuth CR, Glynn RJ, Neumann P, Maclure M, Brookhart AM, Schneeweiss S. Impact of two sequential drug cost-sharing policies on the use of inhaled medications in older patients with chronic obstructive pulmonary disease or asthma. Clin Ther. 2006;28(6):964-78. 
52. Schneeweiss S, Patrick AR, Maclure M, Dormuth CR, Glynn RJ. Adherence to statin therapy under drug cost sharing in patients with and without acute myocardial infarction: a population-based natural experiment. Circulation. 2007;115(16):2128-35.

53. Schneeweiss S, Patrick AR, Maclure M, Dormuth CR, Glynn RJ. Adherence to beta-blocker therapy under drug cost-sharing in patients with and without acute myocardial infarction. Am J Manag Care. 2007;13(8):445-52.

54. Goldsmith L, Kolhatkar A, Popowich D, Holbrook AM, Morgan SG, Law MR. Understanding the patient experience of cost-related non-adherence to prescription medications through typology development and application. Soc Sci Med. 2017;194:51-9.

55. Gupta S, McColl MA, Guilcher SJT, Smith K. Managing medication cost burden: a qualitative study exploring experiences of people with disabilities in Canada. Int J Environ Res Public Health. 2019;16(17):3066.

56. Tamblyn R, Laprise R, Hanley JA, Abrahamowicz M, Scott S, Mayo N, et al. Adverse events associated with prescription drug cost-sharing among poor and elderly persons. J Am Med Assoc. 2001;285(4):421-9.

57. Pilote $L$, Beck $C$, Richard $H$, Eisenberg MJ. The effects of cost-sharing on essential drug prescriptions, utilization of medical care and outcomes after acute myocardial infarction in elderly patients. CMAJ. 2002;167(3):246-52.

58. Persaud N, Bedard M, Boozary AS, Glazier RH, Gomes T, Hwang SW, et al. Effect on treatment adherence of distributing essential medicines at no charge: the CLEAN Meds Randomized Clinical Trial. JAMA Intern Med. 2020; 180(1):27-34.

59. Krol BL. The effect of free distribution of essential medicines on adherence by income sources and level. Toronto: University of Toronto; 2019.

60. Government of Canada. Non-insured health benefits for First Nations and Inuit [Available from: https://www.canada.ca/en/indigenous-services-canada/ services/non-insured-health-benefits-first-nations-inuit.html. Accessed $25 \mathrm{Mar}$ 2020.

61. Alba AC, Agoritsas T, Walsh M, Hanna S, lorio A, Devereaux PJ, et al. Discrimination and calibration of clinical prediction models: users' guides to the medical literature. JAMA. 2017;318(14):1377-84

62. Nieuwlaat R, Wilczynski N, Navarro T, Hobson N, Jeffery R, Keepanasseril A, et al. Interventions for enhancing medication adherence. Cochrane Database Syst Rev. 2014;11:CD000011.

63. Wang TY, Kaltenbach LA, Cannon CP, Fonarow GC, Choudhry NK, Henry TD, et al. Effect of medication co-payment vouchers on P2Y12 inhibitor use and major adverse cardiovascular events among patients with myocardial infarction: the ARTEMIS randomized clinical trial effect of co-payment vouchers on antiplatelet adherence and CVD events effect of co-payment vouchers on antiplatelet adherence and CVD events. JAMA. 2019;321(1):44-55.

64. Canada Go. Towards implementation of National Pharmacare Discussion Paper 2018 [Available from: https://www.canada.ca/content/dam/hc-sc/ documents/corporate/publications/council_on_pharmacare_EN.PDF.

65. Acri K. The unintended consequences of National Pharmacare Programs: the experiences of Australia, New Zealand, and the UK 2018 [Available from: https://www.fraserinstitute.org/studies/unintended-consequences-ofnational-pharmacare-programs.

\section{Publisher's Note}

Springer Nature remains neutral with regard to jurisdictional claims in published maps and institutional affiliations.

Ready to submit your research? Choose BMC and benefit from:

- fast, convenient online submission

- thorough peer review by experienced researchers in your field

- rapid publication on acceptance

- support for research data, including large and complex data types

- gold Open Access which fosters wider collaboration and increased citations

- maximum visibility for your research: over $100 \mathrm{M}$ website views per year

At BMC, research is always in progress.

Learn more biomedcentral.com/submissions 